Original Research Paper

\title{
The Influence of Local Wisdom on the Actualisation of Educative, Scientific and Religious Behaviour on anAcademic Environment in a University
}

\author{
Edi Suryadi and Kusnendi \\ Faculty of Economics and Business Education, Universitas Pendidikan Indonesia, Indonesia
}

\author{
Article history \\ Received: 25-02-2016 \\ Revised: 29-04-2016 \\ Accepted: $30-04-2016$ \\ Corresponding Author: \\ Edi Suryadi \\ Faculty of Economics and \\ Business Education,Universitas \\ Pendidikan Indonesia, \\ Indonesia \\ Email:suryadi.edi18@yahoo.com
}

\begin{abstract}
This paper examines the influence of local wisdom on academic environment in an Institution of higher education. The Sundanese values have been used as a case in point to examine how culture, scientific and religious values can influence educationwithin an academic society. In Sundanese culture, we find patterned intellectual and moral creativity which contains a system ofmoral values and norms as a form of etiquette, which are interrelated and adhere to tried and tested values, considered worthy, valuable and important and can function as a guide within an academic environment. In regard to this view, the present research attempts to establish: the values of Sundanese local wisdom believed-in and professed by Universitas Pendidikan Indonesia's academic society, in specific by the heads of study programmes and departments; the key values ofscientific, educative and religious behaviour actualised in UPI academic society; and the strengths and weaknesses of key Sundanese local values whichinfluence the level of actualisation of scientific, educative and religious behaviour of Universitas Pendidikan Indonesia. In conclusion, this study has established that Sundanese local valuesembraced by Universitas Pendidikan Indonesia's academic environment are characterised by nine indicators, which aremodeling, caring, discussion, providing guidance, putting the public interest first, gentleness, prioritising dialogue, friendliness and lovingness. Empirically, as a theoritical construct, actualisation of scientific behaviour by Universitas Pendidikan Indonesia's academic environment is characterised by five indicators, which are flexibilityand openness to scientific ideas, critical questioning, environmental sensitivity, curiosity and understanding and searching for evidence before accepting statements.
\end{abstract}

Keywords: University, Sundanese, Local Wisdom, Academic Environment and or Academics

\section{Introduction}

The Sundanese community, just like other Indonesian ethnic groups, has a number of cultural moral value systems, existing in the form of Sundanese culture. The Sundanese cultural value system shapes its own ethnic identity, which is based on values, beliefs and local cultural heritage, which is a reference for behaviour (Ekajati, 1995b). Sundanese culture as a physical attainment of Sundanese ethnicity is in the form of a patterned intellectual and moral creativity and contains a system ofmoral values and norms as a form of etiquette, which are interrelated and adhere to a Sundanese ethnic environment, which is believed to have been tried and tested, so it is considered worthy, valuable and important and functions as guidance, a provider of direction and orientation to community members and also known as cultural value orientation (Rusyana, 2001).

In the perspective of this study, moral values are viewed as local traditional wisdom values.Local wisdom forms the attitudes, perspectives and abilities 
of a community in managing the spiritualand material environment, which provides a community with its ability to endure and grow. Local wisdom forms a creative answer to a geographic-geopolitical,historical and situational local development. Local traditional wisdom is a term related to the cultural moral value order of a community (Saini, 2001).

One form, or model, of Sundanese ethnic local traditional wisdom which has recently been adopted as the motto of the West Java Provincial Government and also become a national motto is reflected in the sentence "Silih Asih Silih Asah dan Silih Asuh". The concept of Silih asihteaches that mankind must love each other. If there is poverty and misfortune, we should come and help each other out without needing to be instructed to, as is the case if stricken with fear, automatically safety and calm will be created so that our fellows are no longer afraid. The concept of silih asah requires fellow humans to each develop their intellect and insight. There is no sabotage or hiding information. Intelligence results in courageous and critical people. The more intelligent people, the more it shows good silaturahmi (brotherhood). Related to this, there is no (social) classification; all are equal, as all human beings are our relatives. There is a shared responsibility to protect attempts to increase intellect. The concept of silih asuh teaches us to take care of each other, so we are free from unpleasant characteristics. Watawa saubil haq and watawa saubis sobr seem to match this concept well, as they are both about charitable care giving.

The Indonesian University of Education, Universitas Pendidikan Indonesia (UPI), located in West Java, is considered a "miniature Indonesia" and has developed an educative, scientific and religious value system. Understanding these educative, scientific and religious concepts is not easy. These three concepts do not stand alone, but are interrelated. According to the humanist perspective, being religious forms a pre-condition for creating an intellectual society. Sheer intellectual intelligence unsupported by spiritual values is evil knowledge and destruction of nature. Meanwhile, spirituality and good character without the support of healthyreasoning can be described as a cause ofinertness, misdirected fanaticism and a cultural setback (Radiana, 2004). Because of this, the religiousness in Universitas Pendidikan Indonesia's motto is a foundation for educative and scientific behaviour. This philosophy, based on the way of thinking, as described above, is internalised by academics at the University in their attempt to develop the national intellect (SK Rektor UPI, 2005).

\section{Theoretical Study, Thought Framework and Hypothosis}

\section{Value Concept}

There is a difference of opinion amongst experts in interpretingthe concept of values. Rokeach differentiates value as "a person has value" andvalue as "an object has value". In a more extreme way, Skinner (1971), claims values issomething held only by humans andlater, it is humans who value or evaluate the outside world, which is essentially without value. This perspective assumes value is something possessed by an object, so this perspective underlines value as belonging to objects.

Related to which aspects are considered to illustrate values or a complete value system, the definition of values looks different. Clyde Kluckhohn as cited by Danandjaja (1986) is of the opinion that value is a clear conception, whether expressed or implicit, from an individual or a specific group about what should be desired, which influences choice of target aims and behaviour. Meanwhile, Rokeach (1973) believes that values are everlasting beliefs that a specific way of acting, or a personal or social aim of existence is more desireable than an opposing or different way of action or life purpose. This differs again from the perspective of (George, 1993), who is of the opinion that values form a perceptual framework, which is relatively permanent. This framework shapes and influences itself from a person's behavioural disposition in general. Kluckhohn (1951) defines values as conception, while Rokeach (1973) interprets it as belief, namely belief about what is right and not right, belief which evaluates objects as good or bad and belief which deems a means or aim as desirable or undesirable, because of which this belief is prescriptive or proscriptive.

A definition of values which stresses the cognitive or affective aspect was proposed by (Jones and Gerard, 1967), namely that "A value expresses a relationship between a person's emotional feeling and particular cognitive categories". At the same time, there are several social scientists who, in defining values, stress values more as standards or criteria about what is rightly, or should be, acceptable, while functioning as guidance to choose actions, aims and development as well as preserving a person's attitudes. This stress is supported by (Kohn, 1969; Raven and Rubin, 1976). From the various definitions, the following can be concluded:

- Values form a conception and at the same time a belief

- Values are related to aspects deemed imporant and "should be" or "rightly" desireable, which are imperative and preferred 
- Values are relatively fixed, but this does not mean they cannot change or be changed

- Values function as a standard or guidance, used by a person in their life

- Values can be explicit or implicit

- Values are oriented towards aims

- Values are motivational, in the sense that they provide direction, but not as a source of energy

\section{Values Contained within Sundanese Cultural Local Wisdom}

Sundanese cultural values are the values possessed by Sundanese people and society and believed to be the truth, so give rise to the willpower for Sundanese people and society to achieve this. According to Djahiri (2006) Sundanese culture provides a cultural pattern and cultural practices for Sundanese society.

Sundanese culture, like other ethnic groups, has a number of cultural moral value systems occuring in the form of complex ideas, cultural activities or patterned behaviours and or as cultural physical creation of Sundanese ethnicity, which contribute to the Sundanese ethnic identity. According to Tajfel (1978) a person's ethnic identity is part of their individual self-concept, which originates from their awareness of membership in an ethnic group, together with values and emotional significance associated with this membership. Ekajati (1995a) claims that Sundanese cultural moral values form a Sundanese ethnic identity, based on Sundanese cultural values, beliefs and heritage, which become a reference for behaviour.

Many experts have undertaken research on Sundanese cultural values, from a variety of perspectives. For example, Tessier (1983) studied moral values which might have existed at the time of Prabu Siliwangi, Danasasmita (1986) on the other hand examined the values found within the Kanekes
Community (Warnaen, 1987). With reference to the results of these various studies, the local wisdom values which have become life-guidance for Sundanese Society are summarised in the following Table 1 .

\section{Scientific, Educative and Religious Behaviour}

Mednick, Higgins and Kirschenbaum (Ndraha, 2003), propose that behaviour is operational and actualisation of a person or group's attitude towards an environmental situation and condition (nature, society, technololgy, or organisation). Meanwhile, attitudes are operationalisation and actualisation of stance. Taliziduhu (1997) states that behaviour in psychology is defined as the activities of an organism which can be observed by another organism or by various research instruments, which includes verbal reporting on subjective conscious experience.

Individual behaviour is shaped from interaction between an individual and the environment. Thoha (1996) proposes that behaviour is a function of interaction between an individual and the environment. This means that being in a second environment will directly determine that person's behaviour. As a result, one person's behaviour will differ from anothers, according to their own environments.

O'Neil (2002) explains that there are three concepts of behaviour. These three concepts are difficult to study, as the three terms are often confused. Firstly, connative behaviour, which is behaviour which has an implicit aim, but is not a conscious aim. Secondly, volitional behaviour, which is conscious connative behaviour, where the individual really has an aim in their mind. Thirdly, normative behaviour, which is behaviour implicitly or explicitly directed by certain ideas (abstract concepts or perspectives), related to what is generally considered good or desired. At a certain level, all behaviour starts out as connative.

Table 1. Crystalisation of sundanes cultural moral values

\begin{tabular}{|c|c|}
\hline Element & Attitude/behaviour \\
\hline Sundanese cultural values humans with God & $\begin{array}{l}\text { Immortality, freedom, obedient, strong determination, } \\
\text { whole-hearted, remorseful, faithful, thankful, fair, jihad, learning tauhid, } \\
\text { realistic, patient, worshipping andbelieve superstitions. }\end{array}$ \\
\hline $\begin{array}{l}\text { Sundanese cultural moral valuesin the } \\
\text { relationship between humans and the self }\end{array}$ & $\begin{array}{l}\text { Welfare, honest, creative, open-minded, faithful, altruism, independent, careful, } \\
\text { patient, thankful, nice, smart,wise, strong, brave, cautious, introspectionand healthy. }\end{array}$ \\
\hline $\begin{array}{l}\text { Sundanese cultural moral valuesin the } \\
\text { relationship between humans and society }\end{array}$ & $\begin{array}{l}\text { Protect each other, convincing, tolerance, respect each other, fair, accepting, } \\
\text { sincere, honest, caring, seeking intellecutal development, nurturing, faithful, } \\
\text { altruism, law-abiding, welfare, thrifty, courageous, ethical, quick to } \\
\text { understand, mature,choosey and careful. }\end{array}$ \\
\hline $\begin{array}{l}\text { Sundanese cultural moral valuesin the } \\
\text { relationship betweenhumans and nature }\end{array}$ & $\begin{array}{l}\text { Harmony, balance, beauty, eternal brotherhood, neat, responsible, peace, love, } \\
\text { preserve, ethical, aesthetic, fair and caring. }\end{array}$ \\
\hline $\begin{array}{l}\text { Sundanese cultural moral valuesin human } \\
\text { relationships in the attempt to fulfilinner } \\
\text { and outer needs }\end{array}$ & $\begin{array}{l}\text { Wise, safety, self-control, submissive, rational, smart, respect each other, } \\
\text { heroism, healthy body and soul, non-hedonist, aware of death, simple, enterprising } \\
\text { (creative), welfare, accept fate (sincerely), excel, impervious, patient, } \\
\text { progressive, tolerantandaim for perfection, as well as introspection. }\end{array}$ \\
\hline
\end{tabular}


Some connative behaviour becomes conscious (or takes on clear values) and becomes volitional. Some volitional behaviour is founded on higher level thinking which involves abstract expression about what is good and bad, right and wrong and becomes normative. At its peak, behaviour reflects assimilation of all three. In the final analysis, connative behaviour is wider and more encompassing of external normative behaviour than volitional and this volitional behaviour develops from connative.

Interpreting educative, scientific and religious behaviour is basically not an easy matter. These three successive words do not stand alone, but are interrelated. According to a number of Bachelors of Education, the humanist-religious perspective is a precondition for creating an intellectually-charactered society. Intellectual intellegence without the support of spiritual values is evil science and destruction of nature. Meanwhile, spirituality and good character without the support of healthyreasoning can be described as a cause ofinertness, misdirected fanaticism and a cultural setback (Radiana 2004).

Educative can be interpreted as a perspective or behaviour based on value considerations and usefulness of an action and thought. Scientific is a framework of view about evaluation, based on a healthy, systematic reasoning. The scientific context is related to the correct thought process (scientific logic), where according to the process meant, correct thought can be called correct if it fulfils certain criteria: Clarification about what something is (ontology), clarificatin about how something can be explained in detail (epistemology) and clarification about what something is for/how it is used (axiology) (Suryasumantri, 2003). Scientific behaviour, based on the correct thought process, will be achieved through the route of education and this behaviour will be shaped through educative behaviour.

So people do not misuse the knowledge they possess, their behaviour must be limited through consideration of the limits of ethical values, morality and religious values. The religious paradigm may sound foreign in the West, but Indonesian society is no stranger to the spiritual value order. 'Religious' in the motto of Universitas Pendidikan Indonesia is not just tagged on to the end, but rather forms the foundation of educative and scientific behaviour. Religious is interpreted as a perspective based on a religious system, where the system meant is not shaped by human ideas (ideology), but based on Ilaahiah values and holistic-trancendental perspectives. As a part of Sundanese society, the religious values held by Universitas Pendidikan Indonesiaare in the form of religious values which correlate tightly with Islamic values.

\section{The Relationship between Values and Behaviour}

The thought framework of this research is an adaptation from the SOBC psychological approach on human behaviour. Stimulus (S) represents situations which provide stimuli for Organisms (O) or individuals. Inan organisation stimuli is meant as everything which exists within the environment and also all psychological aspects which can be perceived, internalised and experienced by an individual. Individuals always interact with the environment. The results of this interaction give rise to perception or interpretation of stimuli, which eventually give rise to Behaviour (B), whether overt or covert. Subsequently, the behaviour displayed by an individual will lead to changes in the environment in the form of Consequences (C). The SOBC model explais that betweenbehaviour and/or consequences in the individual, a feedback process occurs. This means that the individual experiences a social learning process from the behaviour or consequences obtained. Feedback also occurs between behaviour and stimulus.

To clarify and organise the variables involved in this research, as well as the matrix of relationships between one variable and the others, the conceptual framework above will be extended using a conceptual framework adapted from Smith et al. (1969) as shown in Fig. 1.

The individual value system is formed through a socialisation process which continues throughout life within a cultural environment framework (P-1). The cultural environment meant is the ethnic Sundanese local wisdom (Silih Asih, Silih Asah, Silih Asuh). The individual place a cultural environment is socialised is in the form of a relatively long lasting environment, which shapes personality, value systems and individual beliefs (UPI academic society).

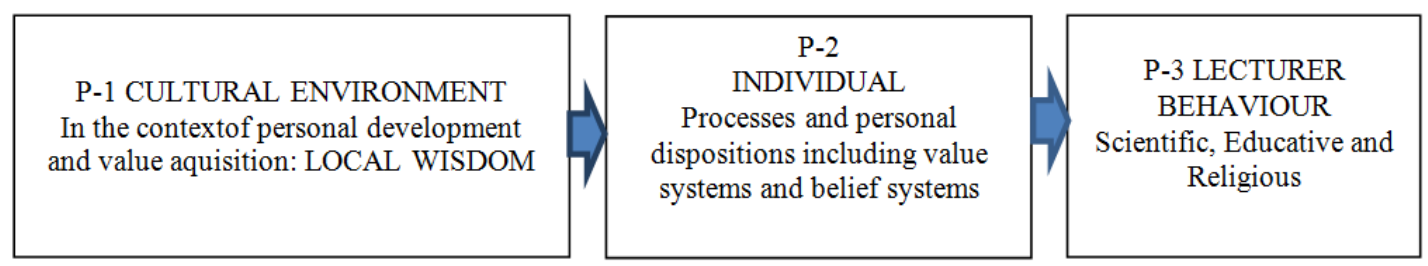

Fig. 1. Research thought framework 
The specific characteristics of a cultural environment are formed from the historical legacy in the fields of politics, economy and socio-culture, as well as the past social structure, which may still be relevant in influencing current behaviour. So the individuals (P2) are always within an environment and between individuals and the environment connected to them is an interactive relationship, where the individual is not only passive or reactive to the environment, but also actively searching for and having stimuli appropriate to values, needs and other experience. Meanwhile, individual behaviour (P-3) is performed as a response to environment $(\mathrm{P}-1)$. Individual behaviour $(\mathrm{P}-3)$ will provide feedback to the individual and feedback to the environment $(\mathrm{P}-1)$. With reference to the above thought framework, three hypothoses have been formulated, which are:

\section{Hypothesis 1}

Strength or weakness of the values of Sundanese local wisdom embraced has a positive influence on the level of scientific behaviour of UPI academic society.

\section{Hypothesis 2}

Strength or weakness of the values of Sundanese local wisdom embraced has a positive influence on the level of educative behaviour of UPI academic society.

\section{Hypothesis 3}

Strength or weakness of the values of Sundanese local wisdom embraced has a positive influence on the level of religious behaviour of UPI academic society.

\section{Research Method}

The object of study, seen from the variables studied, comprises four variables, namely Sundanese local wisdom, scientific behaviour, educative behaviour andreligious behaviour. Data analysis was undertaken in two stages. First, testing validity and reliability of the research questionnaire. First stage data analysis results output is hoped to obtain research variable raw data panel, with question items with tested validity and reliability. Second, testing the proposed model. Model testing analysis technique will use Structural Equation Model (SEM). Choice of SEM takes into account that all research variables are unobserved variables. In this context,SEM is a multivariant dependency data analysis technique used to test descriptive models and structural models simultaneously (Schumacker and Lomax, 1996; Maruyama, 1997; Hair et al., 1998; Kusnendi, 2005; 2007).

The descriptive model explains the latent variable measurement model according to measurable indicators (manifest variables). While the structural model explains the causal relationship between latent variables studied.In the SEM format, the descriptive model andstructural model are translated into a hybrid model, shown in Fig. 2. In this research, this hybrid model is referred to as the UPI Model.

Model testing was undertaken in two stages. The first stage was an overall model fit test and the second stage was an individual parameter model test. The aim was to test the proposed research hypotheses. The test statistic used was Critical Ratio (CR).

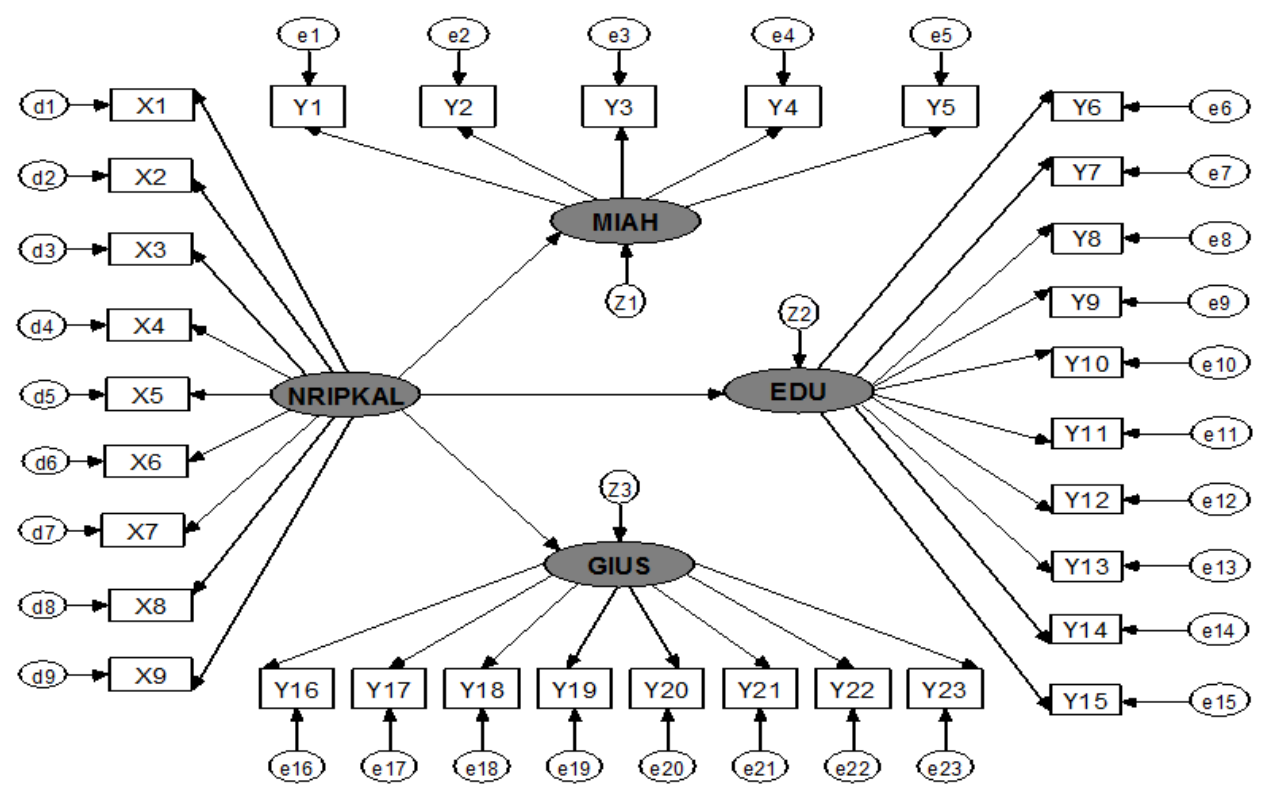

Fig. 2. Hybrid model sundanese local wisdom research and scientific, religious and educative behaviour 
Under the test criteria, if the value of $C R$ is greater than 2 , or the value of $P$-count statistic $C r$ is less or equal to 0.05 , this indicates a significant estimation result. This means hypothesis nil is rejected and alternative hypothesese are accepted.

\section{Research Results}

As has been explained, in this research there are three research problems proposed, they are:

- How are Sundanese local wisdom values embraced in UPI academic society

- How is the actualisation of scientific, educative and religious behaviour in the circle of UPI academic society

- Is the high or low level of actualisation of scientific, educative and religious behaviour in the circle of UPI academic society influenced by Sundanese local wisdom values
To answer these three problems, data was analysed and models tested. The results are summarized in Table 2. Referring to the data analysis results and model testing, the answer to the three research problems is presented in the following discussion.

\section{Sundanese Local Wisdom Values Embraced by UPI Academic Society}

Referring to the model test results, obtained information that the NRIPKAL construct embraced by UPI lecturers is characterised by nine indicators. These nine indicators if ordered according to estimated coefficient weight factor are modeling (X7), having awareness (X4), formal discussion (musyawarah) (X9), providing guidance (X5), putting the public interest first (X6), full of tenderness (X3), putting forward dialogue (X8), courteous (X1) andcaring (X2).

Table 2. Estimation and parameter testing of UPI model (Standardized)

\begin{tabular}{|c|c|c|c|c|}
\hline Equation & Estimate & SE & $\mathrm{CR}$ & $\mathrm{P}$ \\
\hline $\begin{array}{l}\text { EDU<---NRIPKAL } \\
\end{array}$ & 0.7979 & 0.2147 & 4.0667 & *** \\
\hline GIUS<---NRIPKAL & 0.7165 & 0.1714 & 3.6077 & $* * *$ \\
\hline MIAH<---NRIPKAL & 0.8033 & 0.2383 & 4.3930 & $* * *$ \\
\hline Y17<---GIUS & 0.6022 & 0.2873 & 4.0077 & $* * *$ \\
\hline Y5<---MIAH & 0.7802 & 0.2031 & 6.1847 & $* * *$ \\
\hline Y4<---MIAH & 0.8271 & 0.1716 & 6.5342 & $* * *$ \\
\hline Y $2<---M I A H$ & 0.6113 & 0.1653 & 4.8891 & $* * *$ \\
\hline Y1<---MIAH & 0.6999 & & & \\
\hline Y9<---EDU & 0.6312 & 0.1989 & 4.5211 & $* * *$ \\
\hline X5<---NRIPKAL & 0.6900 & 0.2647 & 4.8112 & $* * *$ \\
\hline X4<---NRIPKAL & 0.7351 & 0.2910 & 5.0389 & $* * *$ \\
\hline X6<---NRIPKAL & 0.6483 & 0.2169 & 4.5898 & $* * *$ \\
\hline X3<---NRIPKAL & 0.6322 & 0.2514 & 4.5014 & $* * *$ \\
\hline X7<---NRIPKAL & 0.7626 & 0.2141 & 5.1721 & $* * *$ \\
\hline X2<---NRIPKAL & 0.5763 & 0.2549 & 4.1831 & $* * *$ \\
\hline X9<---NRIPKAL & 0.7279 & 0.2196 & 5.0035 & $* * *$ \\
\hline X8<---NRIPKAL & 0.6282 & 0.2430 & 4.4792 & $* * *$ \\
\hline X1<---NRIPKAL & 0.6107 & & & \\
\hline Y3<---MIAH & 0.9202 & 0.1746 & 7.1482 & $* * *$ \\
\hline Y15<---EDU & 0.5547 & 0.2437 & 4.0577 & $* * *$ \\
\hline Y6<---EDU & 0.6373 & & & \\
\hline Y18<---GIUS & 0.6999 & 0.2807 & 4.4271 & $* * *$ \\
\hline Y21<---GIUS & 0.7499 & 0.3743 & 4.6165 & $* * *$ \\
\hline Y19<---GIUS & 0.6549 & 0.2496 & 4.2420 & $* * *$ \\
\hline Y20<---GIUS & 0.7451 & 0.3385 & 4.5992 & $* * *$ \\
\hline Y22<---GIUS & 0.7371 & 0.3606 & 4.5698 & $* * *$ \\
\hline Y23<---GIUS & 0.7047 & 0.3182 & 4.4459 & $* * *$ \\
\hline Y16<---GIUS & 0.5651 & & & \\
\hline Y7<---EDU & 0.5084 & 0.1866 & 3.7624 & $* * *$ \\
\hline Y8<---EDU & 0.5381 & 0.2041 & 3.9530 & $* * *$ \\
\hline \multirow[t]{2}{*}{ Y13<---EDU } & 0.4269 & 0.1940 & 3.2187 & \\
\hline & 0.0013 & & & \\
\hline Y14<---EDU & 0.6399 & 0.1765 & 4.5716 & $* * *$ \\
\hline Y $12<---E D U$ & 0.6955 & 0.2136 & 4.8855 & $* * *$ \\
\hline Y10<---EDU & 0.6642 & 0.2179 & 4.7110 & $* * *$ \\
\hline Y11<---EDU & 0.6428 & 0.2373 & 4.5884 & $* * *$ \\
\hline
\end{tabular}

Determinant of sample covariance matrix $=50060,0693$ 
Several important findings surfaced from the descriptive data analysis results about Sundanese local wisdom values embraced by the UPI academic society, namely:

- Sundanese local wisdom values as reflected in the silih asih, silih asah, dan silih asuh attitude arenot yetembraced strongly by the UPI academic society

- Sundanes local wisdom values as reflected in the corteous attitude tend to be believed and embraced strongly by the UPI academic society, in comparison to other Sundanese local wisdom values

\section{Actualisation of Scientific, Educative and Religious Behaviour of Universitas Pendidiakn Indonesia (UPI) Academic Society}

\section{Actualisation of Scientific Behavour of UPI Academic Society}

Referring to UPI Model test results in advance objective information was obtained that, seen according to theoretical constructs, scientific behaviour (MIAH) of UPI lectureres is characterised by five indicators. These five indicators if put in order according to estimated co-efficient weight factor are flexible and open to scientific ideas (Y3), critical questioning norm (Y4), environmentally sensitive (Y5), curious and understanding (Y1) and a norm of looking for evidence before accepting a statement (Y2).

Seen from the variables shaping indicators of scientific behaviour for UPI academic society, as well as categorisation criteria used, indication information obtained shows that:

- The level of actualisation of scientific behaviour as reflected in curiousity and understanding is as large as the norm of looking for evidence before accepting a statement, flexible and open to scientific ideas, the critical questioning norm and environmentally sensitive and able to face critical moments in order to find a solution are in the category of medium or moderate

- The level of scientific behaviour as reflected in curious and understanding behaviour, flexible and open to scientific ideas and able to face critical moments to find a solution to problems are in the category high. Meanwhile, scientific behaviour as reflected in the norm of looking for evidence before believing a statement, a critical questioning norm and environmentally sensitive behaviour are in the category of medium or moderate
Actualisationn of Educative Behaviour of Universitas Pendidikan Indonesia's Academic Society

Based on theUPI Model, information was obtained that, seen according to the theoretical construct, educative behaviour (EDU), UPI lecturers are characterised by ten indicators. These ten indicators if put in order according to the estimated coefficient weight factor are virtuousness (Y12), initiative (Y10), work ethos (Y11), patriotic (Y14), dicipline (Y6), autonomy (Y9), scientific and technological orientation (Y15), social responsibility (Y8), self-control (Y7) and tolerance (Y13).

Seen from the variables shaping indicators of educative behaviour for UPI academic society, as well as categorisation criteria used, indication information obtained shows that:

- The level of actualisation of educative behaviour as reflected in discipline, ability to control, selfrestraint links to social groups, autonomy concerningpersonal decisions, initiative, high work ethos, virtuousness, toterant, patriotic and behaviour oriented towards science and technology are in the category medium or moderate

- The level of actualisaion of educative behaviour as reflected in dicipline; ability to control, selfrestraint; initiative, high work ethos; and patriotic behaviourare in the category medium or moderate. Meanwhile, educative behaviour as reflected in behaviour related to social groups, autonomy concerning personal decisions, virtuousness; tolerance; and orientation towards science and technology are in the categoryhigh

\section{Actualisation of Religious Behaviour in UPI Academic Society}

Referring to the UPI Model, information is obtained that, seen according to the theoretical construct, religious behaviour (GIUS) of UPI lecturers is chactised by eight indicators. These eight indicators, if put in order according to the estimated coefficient weight factor, arerepetency (Y21), aware of the greatness of God the Almighty (Y20), possess inner strength (Y22), belief in God (Y23), preserve morals and control behaviour (Y18), brotherhood/silaturahmi (Y19), distance themselves from bad words and deeds (Y17) andbeing faithful (Y16). Several important findings which can be proposed from the descriptive data analysis results on religious behaviour of UPI academic society are:

- The level of actualisatin of UPI academic society as reflected in behaviour believing in God Almighty, 
distancing oneself from useless words and deeds, preserving morals and cotrolling conduct andbad behaviour, respecting and loving relatives, able to read signs of God Almighty in the cosmos, if mistakes have been made, immediatelyrepent andnot repeating these deeds, possessing inner strength and the ability to solve problems are in the high category

- The level of actualisation of religious behaviur reflected in the behaviour: If mistakes have been made, immediatelyrepenting and not repeating those deeds and having inner strength as well as being able to face life problems, on average had a lower score, in the medium ormoderate category. Meanwhile, religious behaviour as reflected in believing in God Almighty, distancing oneself from useless words and deeds, preserving morals as well as controlling conduct and bad behaviour, respecting and loving relatives, able to read signs of the greatness of God Almighty in the cosmos and able to face critical moments to solve problems, are in thehigh category

\section{Influence of SundaneseLocal Wisdom Values on Actualisation of Scientific, Educative and Religious Behaviour for the UPI Academic Community}

Referring to data analysis results as explained above, MIAH, EDU and GIUS structural model parameter estimation results were obtained as follows:

- $\quad$ Model MIAH

$\mathrm{MIAH}=0.8033 \mathrm{NRIPKAL}+\mathrm{z}_{1} ; \mathrm{R}^{2}=0.6454$

- Model EDU

$\mathrm{EDU}=0.7979 \mathrm{NRIPKAL}+\mathrm{z}_{2} ; \mathrm{R}^{2}=0.6366$

- Model GIUS

GIUS $=0.7165$ NRIPKAL $+\mathrm{z}_{3} ; \mathrm{R}^{2}=0.5134$

Information obtained from paramater estimation results of the three models above shows that the level of actualisation of scientific behaviour (MIAH) in the sphere of UPI academic society is influenced by the strength or weakness of Sundanese local wisdom values embraced to the tune of 0.8033 . This means that the actualisation variance of scientific behaviour positively displayed by UPI academic society can $64.54 \%$ be explained by variance in the strength or weakness of Sundanese local wisdom values embraced. The remaining $35.46 \%$ is influenced by variables other than those explained in the model.

The level of actualisation of educative behaviour (EDU) in the sphere of UPI academic society is influenced by the strength or weakness of Sundanese local wisdom values embraced to the tune of 0.7979 . This means that the actualisation variance of educative behaviour positively displayed by UPI academic society can $63.66 \%$ be explained by variance in the strength or weakness of Sundanese local wisdom values embraced. The remaining $36.34 \%$ is influenced by variables other than those explained in the model.

The level of actualisation of religious behaviour (GIUS) in the sphere of UPI academic society is influenced by the strength or weakness of Sundanese local wisdom values embraced to the tune of 0.7165 . This means that the actualisation variance of religious behaviour positively displayed by UPI academic society can $51.34 \%$ be explained by variance in the strength or weakness of Sundanese local wisdom values embraced. The remaining $48.66 \%$ is influenced by variables other than those explained in the model.Related to the research findings as stated above, the following questions arise:

- Why is it that Sundanese local wisdom values as reflected in the values of silih asih, silih, asah and silih asuh are not strongly embraced by UPI academic society

- Why is it that the actualisation of scientific and educative behaviour of UPI academic society is medium, while actualisation of religious behaviour is high

Given that the majority of the UPI academic society are Sundanese, the low level of strength of belief in and emracing Sundanese local wisdom values as reflected in the silih asih, silih asah and silih asuh attitude was extremely unexpected.

As a theoretical ideal, UPI academic society should hold strongly to belief in and embracing of Sundanese local wisdom values, even more so as the results of this research show that the Sundanese local wisdom values tested influence the level of actualisation of scientific, educative and religious behaviour of the UPI academic society. This means that the stronger these Sundanese local wisdom values are embraced by UPI academic society, the higher the level of actualisation of scientific, educative and religious behaviour.

In terms of this unpredicted problem, the weak embrace of Sundanese local wisdom values is caued because until now Sundanese local wisdom has not been considered important in the education process. Alongside this in the context of a global life dynamic where the drastic flow of information through mass or electronic media has coloured, or even erasedevelopment of local wisdom values.

Related to this, UPI shouldhave a commitment to develop and pland Sundanese local wisdom values. Efforts to increase and develop embracement of Sundanese local wisdom values can be undertaken both culturally and structurally. Culturally, this can be achieved through UPI leadership tiered modeling. Meanwhile, structurally this can be undertaken by providingcontentof local wisdom values in each policy implemented. 


\section{Conclusion and Recommendations}

Referring to the data analysis results, hypothesis testing and discussion, the following conclusions can be proposed:

Sundanese local wisdom values (NRIPKAL) embraced by UPI academic society, as a theoretical construct are characterised by nine indicators. These nine indicators aremodeling, caring, discussion (musyawarah), providing guidance, putting the public interst first, smooth/gentleness, prioritising dialogue, friendliness and lovingness. Empirically, these Sundanese local wisdom values are percieved by study program heads to be not strongly embraced by UPI academic society.

As a theoritical construct, actualisation of scientific behaviour by UPI academic society is characterised by five indicators. These five indicators are flexibilityand openness to scientific ideas, critical questioning norm, environmental sensitivity, curiosity and understanding and a norm of looking for evidence before accepting a statement. Emperically, the level of actualisation of scientific behaviour of UPI academic society, based on perceptions of study program heads is in the medium category. This level of actualisation of scientific behaviour is shown in the indicators:curiousity and understanding; norm of looking for evidence before accepting a statement; flexibility and openness to scientific ideas; critical questioning norm; and environmental sensitivity.

As a theoretical construct, actualisation of educative behaviour by UPI academic society is characterised by ten indicators. These ten indicators are: Virtuous; initiative; work ethos; patriotic; dicipline; autonomy; scientific and technological orientation; social responsibility; self control; and tolerance. Empirically, the level of actualisation of educative behaviour of the UPI academic community, based on perceptions of study program heads is in the medium category. This actualisation of educative behaviour can predominantly be seen from the indicators: Dicipline; self control and self restraint; links to social groups; autonomy in making personal decisions; initiative; and a high work ethos. While if we look at the indicators: Virtuous; tolerance; patriotic; andscience and technology orientation, the educative behaviour level tends towards high.

As a theoretical construct, actualisation of religious behaviour of UPI academic society is characterised by eight indicators. These eight indicators are: Repentant; awareness of the greatness of God Almighty; possessing inner strength; ongoing faith; preserving morals and controlling conduct; brotherhood/silaturahmi; distancing one self from unpleasant words and deeds; and faithfulness. Empirically, the level of actualisation of religious behaviour of UPI academic society based on the subjective perceptins of the study program heads is in the high category. This high level of religious behaviour actualisation is shown from the indicators: Belief in Almighty God, distancing oneself from unproductive goods and deeds; preserving morals and controlling conduct and bad behaviour; respecting and loving relatives; able to read signs of the greatness of God Almighty in the natural environment; and able to face critical moments to solve problems. Meanwhile, seen from the indicators of: If mistakes are made, directlyrepent and not repeating the deed; and having inner strength as well as facing personal problems are in the medium category.

The level of actualisation of scientific, educative and religious behaviour in the sphere of UPI academic society is influenced positively by the strength of Sundanese local wisdom values embraced. This means that the stronger the Sundanese local wisdom values held by UPI academic society, the higher the level of actualisation of scientific, educative and religious behaviour.

\section{Focussed on the Research Conclusions are Various Suggestions, as Follows}

The level to which Sundanese local wisdom values are embraced by UPI academic society, as characterised by the values of silih asih, silih asah and silih asuh, should be increased, given that local wisdom values have been empirically tested and proven to increase actualisaion of scientific, educative and religious behaviour. Efforts to increase the level to which Sundanese local wisdom values are embraced can be undertaken culturally or structurally. Culturally this can be undertaken through tiered role-modeling by UPI leaders. Meanwhile, structurally this can be undertaken through providing local wisdom value content in each policy implemented.

Further research needs to be undertaken on scientific, educative and religious behaviour of UPI academic society, including other variables, particularly a control or moderator variable predicted to strongly influencethe causal relationship between actualisation of scientific, educative and religious behaviour of UPI academic society. The variables meant are predominantly related to organizational characteristics, individual characteristics and external environment characteristics, as well as ethnic backgrounds of UPI academic society other than Sundanese.

\section{Acknowledgement}

With the busy schedule throughout the week, having time to write is not easy. Upon this, we wish to thank all those individuals who have supported and above all encouraged us to write this paper. Second, we also wish to thank the reviewers from the American Journal of Applied Sciences who have guided us to improve this 
final paper. Lastly, we thank PT. EDURES Global Link for its continous support in language editing and guidance on scientific writing and international academic publishing. Its founder Dr. Wamaungo Juma Abdu has always encouraged us and also continously guided us on how to write for publication.

\section{Funding Information}

This research was funded by Universitas Pendidikan Indonesia through the Institute for Research and Community Services (LPPM).

\section{Author's Contributions}

Edi Suryadi: As the main author contributed in both writing and finance to make sure this paper reaches the publication stage.

Kusnendi: As a co-author helped very much in writing and re-writing the final copy of this paper.

\section{Ethics}

In the process of writing, all academic principles have been followed. There is no plagiarism of any form.

\section{References}

Skinner, B.F., 1971. Beyond Freedom and Dignity. 1st Edn., Penguin Books, New York, ISBN-10: 0553143727, pp: 215.

Danandjaja, A., 1986. Sistem nilai manajer indonesia, tinjauan kritis berdasar penelitian. PT Pusaka Binaman Pressindo, Jakarta.

Danasasmita, S.A.J.S., 1986. Kehidupan masyarakat kanekes. Departemen Pendidikan dan Kebudayaan Dirjen Kebudayaan Proyek Sundanologi, Bandung.

Djahiri, A.K., 2006. Esensi pendidikan nilai moral dan pkn di era globalisasi dalam pendidikan nilai moral dalam esensi pendidikan kewarganegaraan. Laboratorium Pendidikan Kewarganegaraan FPIPS UPI. Bandung.

Ekajati, E.S., 1995a. Kebudayaan sunda. Pustaka Jaya, Jakarata.

Ekajati, E.S., 1995. Sunda, nusantara, Indonesia. Universitas Padjadjaran, Bandung.

George, E.F., 1993. Plant propagation by tissue culture. Part 2 in Practice. Exegeticts Lim. England.

Hair, J.F.J., R.E. Anderson, R.L. Tatham and W.C. Black, 1998. Multivariate data analysis. Prentice-Hall International, USA.

Jones, E.E. and H.B. Gerard, 1967. Foundations of Social Psychology. 1st Edn., Wiley, New York, pp: 743.

Kluckhohn, 1951. Values and value orientations in the theory of action: An Exploration in definition and classification. Harvard University Press.
Kohn, M.L., 1969. Class and Conformity: A Study in Values. 1st Edn., Dorsey Press, Homewood, pp: 315.

Kusnendi, 2005. Ancangan praktis pengolahan data statistik analisis jalur, analisis faktor konfirmatori dan analisis model persamaan struktural (SEM) melalui aplikasi program SPSS dan SIMPLIS LISREL 8. Universitas Pendidikan Indonesia, Bandung.

Kusnendi, 2007. Model persamaan struktural (SEM) dengan AMOS. LPEK. Program Pendidikan Ekonomi dan Koperasi UPI, Bandung.

Maruyama, G.M., 1997. Basics of Structural Equation Modeling. 1st Edn., SAGE Publications, Thousand Oaks, ISBN-10: 150632035X, pp: 328.

Ndraha, T., 2003. Budaya organisasi. Rineka Cipta, Jakarta.

O’Neil, F.W., 2002. A Question of Trust: The BBC Reith Lectures. 1st Edn., Cambridge University Press, Cambridge, ISBN-10: 0521529964, pp: 100.

Radiana, A., 2004. Pikiran rakyat. Tersedia.

Raven, B.H. and J.Z. Rubin, 1976. Social Psychology: People in Groups. 1st Edn., Wiley, New York, ISBN-10: 0471709700, pp: 591.

Rokeach, M., 1973. The Nature of Human Values. 1st Edn., Free Press, New York, pp: 438.

Rusyana, Y., 2001. Transformasi nilai budaya sunda melalui sistem persekolahan. makalah pada semiloka transformasi nilai budaya sunda. Paguyuban Pasundan, Bandung.

Saini, K.M., 2001. Pendidikan pasundan masa depan (Makalah). Panitia Semiloka Transformasi Nilai Budaya Sunda, Bandung.

Schumacker, R.E. and R.G. Lomax, 1996. A Beginner's Guide to Structural Equation Modeling. 1st Edn Routledge, Jew Jersey, ISBN-10: 1841698903, pp: 510.

SK Rektor UPI, 2005. Platform UPI BHMN.

Smith, P.C., L.M. Kendall and C.L. Hulin, 1969. The Measurement of Satisfaction in Work and Retirement: A Strategy for the Study of Attitudes. 1st Edn., Rand McNally, Chicago, pp: 186.

Suryasumantri, J.S., 2003. Filsafat ilmu: Sebuah pengantar populer. Sinar Harapan, Jakarta.

Taliziduhu, N., 1997. Sistem pemerintahan dan Negara. Rineka Cipta.

Tajfel, H., 1978. Differentiation between Social Groups: Studies in the Social Psychology of Intergroup Relations. 1st Edn., Academic Press, London, pp: 474.

Tessier, V.S., 1983. Cariosan prabu siliwangi. Lembaga Penelitian Prancis untuk Timur Jauh, Jakarata.

Thoha, M., 1996. Perilaku organisasi: Konsep Dasar dan Aplikasi. PT Raja Grafindo Persada, Jakarta.

Warnaen, S., 1987. Pandangan hidup orang sunda. Dirjen Kebudayaan Depdikbud, Bandung. 